\title{
Bacali F2011, variedad de trigo harinero-panadero para su cultivo en el DDR 014, Río Colorado*
}

\section{Bacali F2011, variety of bread-baker wheat for cultivation in the ID 014, Colorado River}

\author{
Jorge Iván Alvarado Padilla ${ }^{1 \S}$, Miguel Alfonso Camacho Casas ${ }^{2}$, Gabriela Chávez Vallalba ${ }^{2}$, Pedro Figueroa López ${ }^{2}$, Eva Ávila \\ Casillas $^{1}$ y Mario Camarillo Pulido ${ }^{1}$ \\ ${ }^{1}$ Campo Experimental Valle de Mexicali-INIFAP. Carretera a San Felipe, km 7.5. C.P. 21700. Mexicali Baja California. Tel. (686) 5 63 6043. Ext. 115. ${ }^{2}$ Campo Experimental \\ Norman E. Borlaug-INIFAP. Norman E. Borlaug, km 12. A. P. 155. Ciudad Obregón, Sonora. C. P. 85000. Tel. (644) 41457 00. ${ }^{\S}$ Autor para correspondencia: alvarado. \\ jorge@inifap.gob.mx.
}

\section{Resumen}

El trigo es el principal cultivo sembrado en el ciclo otoñoinvierno en el Distrito de Riego 014 del Río Colorado(DDR 014), que comprende los Valles de Mexicali, B. C. y San Luis Río Colorado, Sonora (Hernández et al., 2010). En los últimos cinco años (2008 a 2012) la siembra trigo en el DDR 014 promedió 96.975 hectáreas (OEIDRUS, 2013); $83.9 \%$ corresponde al Valle de Mexicali, B. C. donde entre los años el 2011 y 2013 se sembraron 12085 hectáreas de trigo harinero (Triticum aestivum L.), siendo las variedades Cachanilla F2000 con $37.4 \%$, Yécora F70 con $22.9 \%$ y Rayón F89 con 9\% las más sembradas. El programa de mejoramiento genético de trigo del Campo Experimental Valle de Mexicali, perteneciente al Instituto Nacional de Investigaciones Forestales, Agrícolas y Pecuarias (INIFAP), uniendo esfuerzos con el Centro Internacional de Mejoramiento de Maíz y Trigo (CIMMYT), tiene como objetivo generar genotipos de diversos tipos de gluten, para mejorar la rentabilidad y competitividad del cultivo de trigo mediante la liberación de variedades con rendimiento, calidad y sanidad.

Palabras clave: competitividad, gluten, rentabilidad.

\section{Abstract}

Wheat is the main crop sown in the autumn-winter in Irrigation District 014 Río Colorado (ID 014), comprising the Valley of Mexicali, BC and San Luis Río Colorado, Sonora(Hernández etal., 2010). In the last five years (2008-2012) planting wheat in the ID 014 averaged 96975 hectares (OEIDRUS, 2013), $83.9 \%$ corresponds to the Mexicali Valley, BC where between 2011 and 2013 were planted 12085 hectares of bread-wheat (Triticum aestivum L.) varieties being Cachanilla F2000 with $37.4 \%$, Yécora F70 with $22.9 \%$ and Rayon F89 with 9\%. The Wheat Breeding Program of the Experimental Field Mexicali Valley of the National Research Institute ofForestry, Agriculture and Livestock (INIFAP), joining forces with the International Center for Maize and Wheat Improvement (CIMMYT), aims to generate genotypes various types of gluten to improve the profitability and competitiveness of the wheat crop by releasing varieties with yield, quality and health.

Keywords: competitiveness, gluten, profitability.

As a result of the breeding work in recent years, it has been possible to identify and select genotypes with increased yield, quality and resistance to diseases prevalent in the

\footnotetext{
* Recibido: septiembre de 2013

Aceptado: febrero de 2014
} 
Como resultado de los trabajos de mejoramiento genético, en los últimos años ha sido posible identificar y seleccionar genotipos con mayor rendimiento, calidad y resistencia a las enfermedades que prevalecen en la región; así, derivado de las evaluaciones realizadas a partir del ciclo otoño-invierno 2006-2007 hasta 2010-2011, se propuso la liberación de la línea experimental Tobarito 97/Pastor como variedad Bacali F2011, que de acuerdo a las evaluaciones antes mencionadas supera el rendimiento de grano de las variedades Cachanilla F2000 y Rayón F89 en 4 y 5\%, respectivamente. El DDR 014-Río Colorado es considerado una región relativamente libre de enfermedades de trigo, como las royas y los carbones; aunque, se tienen reportes de que en años excepcionales se han observado brotes tardíos y desarrollo erráticos de roya de la hoja (Puccinia recondita o $P$. triticina), y por primera vez, en el ciclo otoño-invierno 2002-2003, de roya amarilla (Puccinia striiformis); sin embargo en los lotes experimentales de trigo durante la evaluación de Bacali F2011 no se observó presencia de enfermedades(Hernández et al., 2011).

El progenitor Pastor postula la presencia del gen Lr23, el cual le brinda la resistencia contra el hongo de la raza $\mathrm{MCJ} / \mathrm{QM}$, el cual causa muerte celular de las hojas, manifestándose como un pequeño punto clorótico y/o necrótico del tamaño de la punta de un alfiler (Huerta y Singh, 2000). Por lo que se considera que esta variedad será una alternativa para incrementar el rendimiento y rentabilidad en la región.

Bacali F2011 es una variedad de trigo harinero de hábito de primavera, producto de la cruza Tobarito 97/ Pastor, cuyo número de cruza e historial de selección es: CMSS97M057565-040M-020Y-030M-015Y-3M-3Y-2M$0 Y$. La selección en poblaciones segregantes se realizó por el método pedigrí modificado, alternando generaciones entre el Valle del Yaqui (Y), Sonora (27 $29^{\prime} \mathrm{N}$ de latitud y $40 \mathrm{msnm}$ ), San Antonio Atizapán (M), Estado de México (19 $17^{\circ}$ latitud norte y $2640 \mathrm{msnm}$ ) y El Bátan (B), Estado de México (1931' latitud norte y $2249 \mathrm{msnm}$ ). En el Valle de Mexicali, B. C., se seleccionó en forma visual en el ciclo otoño-invierno 2005-2006, en el vivero de incremento de semilla experimental de trigo para ensayos internacionales del CIMMYT, realizando las pruebas de rendimiento y calidad a partir del ciclo otoño-invierno 2006-2007 hasta 2010-2011; mientras que la caracterización fenotípica se realizó en el Valle del Yaqui, de acuerdo a los descriptores de la Protección de Nuevas Variedades de Plantas, por sus siglas en inglés (UPOV, 1988). region as well, derived from assessments made from autumn-winter cycle 2006-2007 to 2010-2011, we proposed the release of the experimental line Tobarito 97/Pastor as the variety Bacali F2011, that according to the evaluations outperforms grain varieties of Cachanilla F2000 and Rayon F89 in 4 and 5 are proposed \%, respectively. The ID 014Río Colorado is considered a relatively free region diseases of wheat, as rusts and coals, although there are reports that in exceptional years have seen late outbreaks and erratic development of leaf rust (Puccinia recondita or P. triticina), and for the first time in autumn-winter 2002-2003, yellow rust (Puccinia striiformis) cycle, but in the experimental plots of wheat during the evaluation of Bacali F2011 no presence of disease was observed (Hernández et al., 2011).

The parent Pastor postulated the presence of the gene LR23, which provides resistance to the fungus race $\mathrm{MCJ} / \mathrm{QM}$, which causes cell death of leaves, manifesting as a small point chlorotic and/or necrotic tip size a pin (Huerta and Singh, 2000). It is considered that this variety will be an alternative to improve yield and profitability in the region.

Bacali F2011 is a variety of bread-wheat of spring habit, product of Tobarito 97/Pastor crosses, the number of crossing and selection history is: CMSS97M057565-040M-020Y$015 \mathrm{Y}-030 \mathrm{M}-3 \mathrm{M}-3 \mathrm{Y}-2 \mathrm{M}-0 \mathrm{Y}$. The selection in segregating populations was performed by the modified pedigree method, alternating generations between the Yaqui Valley (Y), Sonora $\left(27^{\circ} 29^{\prime} \mathrm{N}\right.$ latitude and $\left.40 \mathrm{~m}\right)$, San Antonio Atizapán (M), State of Mexico (19 $17^{\prime}$ north latitude and $2640 \mathrm{~m}$ ) and El Batán (B), State of Mexico (19 ${ }^{\circ} 31^{\prime}$ north latitude and $2249 \mathrm{~m}$ ). In the Valley of Mexicali, BC, was selected visually in autumn-winter 2005-2006 in the experimental nursery seed increase of wheat CIMMYT's international testing, performing testing and quality performance from cycle autumn-winter 2006-2007 to 2010-2011, while the phenotypic characterization was performed in the Yaqui Valley, according to the descriptors of the Protection of New Varieties of Plants, (UPOV, 1988).

Bacali F2011 is a variety of bread-baker-wheat (Triticum aestivum L. em. Thell.) of spring habit, insensitive to photoperiod, with an average height of $95 \mathrm{~cm}$, the bloom or flower development occurs at 96 days and the physiological maturity reaches 135 days. The stems are of intermediate growth, with strong serosity neck and with an average frequency of curved flag leaves, the flag leaf sheath has a strong serosity. The density and length of the pin are averages, its pyramidal shape and has a weak waxiness. Short 
Bacali F2011 es una variedad de trigo harinero-panadero (Triticum aestivum L. em. Thell.) de hábito primaveral, insensible al fotoperiodo, con una altura promedio de 95 $\mathrm{cm}$, cuya floración o espigamiento ocurre a los 96 días y la madurez fisiológica la alcanza a los 135 días. Los tallos son de crecimiento intermedio, con cerosidad fuerte en el cuelloy con una frecuencia media de hojas bandera curvadas; la vaina de hoja bandera presenta una fuerte cerosidad. La densidad y longitud de la espiga son medias, su forma piramidal y presenta una cerosidad débil. Las barbas cortas y blancas, se distribuyen a todo lo largo de la espiga; con las de la punta de la espiga mostrando la misma longitud que esta; cuando madura, la espiga adquiere un color blanco con pubescencia muy fuerte en el margen del primer segmento del raquis.

La gluma inferior en las espiguillas del tercio medio de la espiga presenta un hombro de forma elevada y pubescencia débil en la parte interna, la longitud de su punta es mediana y la forma de esta es moderadamente curva. El grano es de color blanco y al ser tratado con fenol adquiere una coloración obscura; al germinar, el coleóptilo y la primera hoja muestran una pigmentación antociánica ausente o muy débil. Con respecto a rendimiento al promedio de los cuatro años de evaluación, Bacali F2011 superó con 4\% a la variedad Cachanilla F2000, tomada como testigo por su superficie sembrada en el DDR-014 (Figura 1).

La variedad de trigo harinero de gluten fuerte BACALI F2011, generada bajo condiciones de riego; manifiesta un peso hectolítrico de $81.8 \mathrm{~kg} \mathrm{hL}^{-1}$, el cual es clasificado como grano de calidad México 1, según la Norma Mexicana NMX-FF-036-1996 que rige la comercialización de trigo a nivel nacional (DGN, 1996). Aun cuando el contenido de proteína en grano generalmente se relaciona inversamente con el rendimiento, una adecuada cantidad y oportunidad de aplicaciónde la fertilización nitrogenadapermiteque el granode BACALIF2011 alcance $12.8 \%$ deproteína, conun rendimiento promedio de $7703 \mathrm{~kg} \mathrm{ha}^{-1}$. La fuerza de su gluten(W) de 362, lo caracteriza como un trigo de gluten fuerte, ligeramente superior a la variedad Cachanilla F2000 (347), por lo que se ha clasificado apta para panificación mecanizada. La relación tenacidad/extensibilidad es otro parámetro de importancia en la calidad del gluten de la harina de trigo panificable, por lo que Bacali F2011, presenta gluten tenaz $(\mathrm{T} / \mathrm{L}=5.5)$, mayor que la variedadCachanillaF2000 $(\mathrm{T} / \mathrm{L}=4.4)$; por ello, se recomienda que la harina de Bacali F2011 se use mezclada con harina de gluten extensible en el proceso mecanizado de panificación. El tiempo de amasado en la harina de Bacali F2011 es de 3 min., con una altura de 4 y un volumen de pan de $783 \mathrm{cc}$. white beard, are distributed throughout the shank, with the tip of the spike showing the same length as this, when ripe, the pin takes on a white color with very strong pubescence in the margin of the first segment rachis.

The lower glume in the spikelets in the middle third of the shank has a raised long-shoulder shaped, weak pubescence on the inner side, the length of the tip is medium, and the shape of this curve is moderately. The grain is white when treated with phenol acquires a dark color, to germinate, the coleoptile and the first leaf show absent or very weak anthocyanin pigmentation. With respect to the averageyield of the four-year evaluation, BacaliF2011 exceeded 4\% in the variety Cachanilla F2000, taken as a witness for his sown in the ID-014 surface.

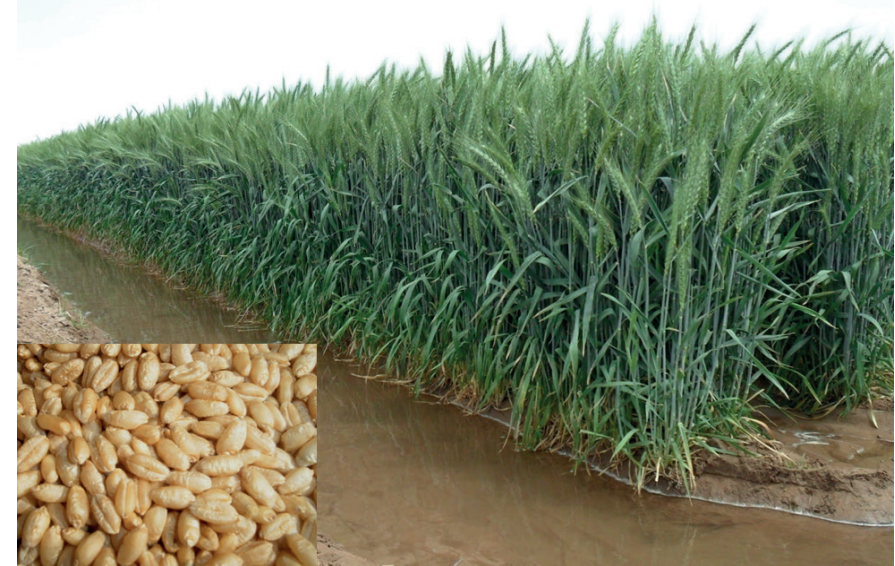

Figura 1. Planta y grano de trigo harinero "Bacali F2011" cultivada en Mexicali, BC.

Figure 1.Plant and grain wheat flour "Bacali F2011" cultivated in Mexicali, BC.

The variety of strong gluten bread-wheat Bacali F2011 generated under irrigation; demonstrates a test weight of $81.8 \mathrm{~kg} \mathrm{hL}^{-1}$, which is classified as grain quality Mexico 1 by NMX-FF-036-1996 governing the marketing of wheat nationally (DGN, 1996). Although the protein content in grain generally adequate amount and timing of application of nitrogen fertilization allows the grain Bacali F2011 reach $12.8 \%$ protein, with an average yield of $7703 \mathrm{~kg} \mathrm{ha}^{-1}$ is inversely related to yield. The strength of the gluten(W) 362 , characterizes it as a strong gluten wheat, slightly higher than therangeCachanillaF2000(347), so it is classified suitable for mechanized bakery. The tenacity/extensibility ratio is another important parameter in the quality of gluten bread-wheat, so Bacali F2011 presents tenacious gluten ( $\mathrm{T} / \mathrm{L}=5.5)$, higher than the range Cachanilla F2000 $(\mathrm{T} / \mathrm{L}=4.4)$, therefore, it is 
La variedad Bacali F2011 fue inscrita en el Catálogo de Variedades Factibles de Certificar (CVC) con el número de registróTRI-125-041011. La semilla básica de Bacali F2011 se puede adquirir en el Campo Experimental Valle de Mexicali del Instituto Nacional de Investigaciones Forestales, Agrícolas y Pecuarias (INIFAP).

\section{Reconocimientos}

Con el nombre de esta variedad, los autores(a) reconocen la destacada labor del M. C. Benjamín Hernández Vázquez, investigador del Programa de Mejoramiento Genético de Trigo del Campo Experimental Valle de Mexicali del INIFAP, en un periodo comprendido de diciembre de 2008 a diciembre de 2012.

\section{Agradecimientos}

Se agradece al Centro de Internacional de Mejoramiento de Maíz y Trigo (CIMMYT), por proporcionar las líneas avanzadas de donde se originó Bacali F2011. De igual manera se agradece a la Fundación Produce Baja California, por el financiamiento parcial de los trabajos de investigación que condujeron a la obtención de la variedad Bacali F2011.

\section{Literatura citada}

Dirección General de Normas (DNG). 1996. Norma Mexicana NMXFF-036-1996. Productos alimenticios no industrializados cereales y trigo. (Triticum aestivum L. y Triticum durum Desf.). Especificaciones y métodos de prueba. 11 p. recommended that the flour used Bacali F2011 mixed with extensible gluten flour in the baking process machining. Kneading time of Bacali F2011 dough is $3 \mathrm{~min}$. With a height of 4 and a volume of $783 \mathrm{cc}$ bread.

The variety was registered Bacali F2011 Catalog Variety Certify Feasible (CVC) with the number of registry TRI125-041011. The basic seed Bacali F2011 is available in the Experimental Field Mexicali Valley of the National Research Institute of Forestry, Agriculture and Livestock (INIFAP).

End of the English version

Hernández-Vásquez, B.; Figueroa, L. P. y Chávez, V. G. 2011. Bacali F2011: variedad de trigo Harinero para Baja California y Norte de Sonora. Instituto Nacional de Investigaciones, Agrícola y Pecuarias (INIFAP). Centro de Investigación Regional del Noroeste. Campo Experimental Valle de Mexicali. Mexicali, Baja California, México Folleto técnico Núm. 17.14 p.

Hernández, V. B.; Guzmán, R. S. de C. y Valenzuela, P. J. A. 2010. Guía para producir trigo en los Valles de Mexicali, B. C. y San Luis Río Colorado, Sonora. Instituto Nacional de Investigaciones Forestales, Agrícolas y Pecuarias (INIFAP). Centro de Investigaciones Regional Noroeste. Campo Experimental Valle de Mexicali. Mexicali, Baja California, México. Folleto para productores Núm. 57.24 .

Huerta, E. J. y Singh, R.P. 2000. Las Royas del Trigo.In: Villaseñor, M.H.E. y Espitia, R.E.(Eds.). El trigo de temporal en México. Chapingo, Estado de México. México. SAGARPA. INIFAP. Campo Experimental Valle deMéxico. LibrotécnicoNúm. 1.231-249pp.

International UnionfortheProtection of New Varieties of Plants. (UPOV). 1988. Internacional guideliness for the conduct of tests for distinctness, homogeneit and stability. DurumWheat (Triticumdurum L.)

Oficina Estatal de Información para el Desarrollo Rural Sustentable del Estado de Sonora (OEIDRUS). 2013. www.oeidrus-sonora. gob.mx. (consultado agosto, 2013).

Oficina Estatal de Información para el Desarrollo Rural Sustentable del Estado de Baja California(OEIDRUS), 2013. www.oeidrus-bc. gob.mx (consultado agosto, 2013). 